\title{
Proposal for qualitative and quantitative descriptors to characterise bamboo germplasm ${ }^{1}$
}

\author{
Proposta de descritores qualitativos e quantitativos para caracterização de \\ germoplasma de bambu
}

\author{
Andressa Leal Generoso ${ }^{2 *}$, Jardel Oliveira Santos ${ }^{3}$, Virginia Silva Carvalho ${ }^{2}$, Nayara Niele Sacoman ${ }^{2}$ e Rosana \\ Rodrigues $^{3}$
}

\begin{abstract}
Bamboo is a genetic resource with evident potential for use from construction until the recovery of degraded areas. Although, characterization and evaluation studies involving bamboo species are scarce and it is difficult to define a list of specific descriptors to better meet the different genres and or bamboo species. Thus, the objective of this work were propose and test the effectiveness of qualitative and quantitative descriptors for phenotypic characterization and the study of genetic diversity among six species of bamboo introduced in Brazil. Fifteen qualitative and nine quantitative descriptors were proposed and tested in clones with one year of planting. Individuals belonging to six species of bamboo (Bambusa vulgaris, Bambusa vulgaris var. vittata, Drepanostachyum falcatum, Dendrocalamus latiforus, Phyllostachys aurea var. albovariegada and Phyllostachys edulis) were characterized on the basis of vegetative descriptors, pseudopetiole, sheath, ligule, gems and culm. The genetic divergence between the clones was estimated by the methods of grouping of Tocher and UPGMA with use of average Euclidean distance and the principal component in two-dimensional plane. Qualitative and quantitative descriptors proposed were efficient to differentiate the six species studied and quantify genetic diversity. The quantitative descriptor of sheath length was the largest contributor to differentiate the species studied.
\end{abstract}

Key words: Bambusa. Drepanostachyum. Dendrocalamus. Phyllostachys. Genetic diversity.

RESUMO - O bambu é um recurso genético com evidente potencial para utilização que vai desde a construção civil até a recuperação de áreas degradadas. Mesmo assim, os estudos de caracterização e avaliação envolvendo espécies de bambu são escassos e dificultam a definição de uma lista de descritores específica para melhor conhecer os diferentes gêneros e/ ou espécies de bambu. Desse modo, objetivou-se neste trabalho propor e testar a eficiência de descritores qualitativos e quantitativos visando à caracterização fenotípica e ao estudo de diversidade genética entre seis espécies de bambu introduzidas no Brasil. Quinze descritores qualitativos e nove quantitativos foram propostos e testados em clones com um ano de plantio. Indivíduos pertencentes a seis espécies de bambu (Bambusa vulgaris, Bambusa vulgaris var. vittata, Drepanostachyum falcatum, Dendrocalamus latiforus, Phyllostachys aurea var. albovariegada e Phyllostachys edulis), foram caracterizados com base em descritores vegetativos de folha, pseudopecíolo, bainha, lígula, gemas e colmo. A divergência genética entre os clones foi estimada pelos métodos de agrupamento de Tocher e UPGMA, com emprego da distância Euclidiana média e pelos Componentes Principais no plano bidimensional. Os descritores qualitativos e quantitativos propostos foram eficientes para diferenciar as seis espécies estudadas e quantificar a diversidade genética. O descritor quantitativo de comprimento da bainha foi o que mais contribuiu para diferenciar as espécies estudadas.

Palavras-chave: Bambusa. Drepanostachyum. Dendrocalamus. Phyllostachys. Diversidade genética.

\footnotetext{
DOI: $10.5935 / 1806-6690.20160006$

* Autor para correspondência

${ }^{1}$ Recebido para publicação em 01/02/2014; aprovado em 07/10/2015

Parte da dissertação de mestrado do primeiro autor apresentada ao programa de pós-graduação em Genética e Melhoramento de Plantas da Universidade Estadual do Norte Fluminense Darcy Ribeiro/UENF

${ }^{2}$ Laboratório de Fitotecnia do Centro de Ciências e Tecnologias Agropecuárias LFIT/CCTA, Universidade Estadual do Norte Fluminense Darcy Ribeiro, Campos dos Goytacazes-RJ, Brasil, andressaleal_caldas@hotmail.com,virginia@uenf.br, nayaranisa@hotmail.com

${ }^{3}$ Laboratório de Melhoramento Genético Vegetal do Centro de Ciências e Tecnologias Agropecuárias LMGV/CCTA, Universidade Estadual do Norte

Fluminense Darcy Ribeiro, Campos dos Goytacazes-RJ, Brasil, jrdl_2@yahoo.com.br, rosana@uenf.br
} 


\section{INTRODUCTION}

The bamboo is a member of the Poaceae family, included in the subfamily Bambusoideae, with 1,439 species (BAMBOO PHYLOGENY GROUP, 2012; SUNGKAEW et al., 2009). Bamboos are distributed throughout the tropical and temperate areas of Asia, Australia, Africa and America (GUERREIRO; LIZARAZU, 2010).

Brazil has a great diversity of bamboo; thirty-three genera and around 250 species can be found, of which about 160 are considered to be endemic, with some that have not yet been formally described. In addition, over 20 species of bamboo have been introduced into Brazil (FILGUEIRAS et al., 2013.), mainly during the colonial period and later by Japanese immigrants, most of these being species native to Asia (SILVA; PEREIRA; SILVA, 2011; TOMBOLATO; GRECO; PINTO, 2012).

There are many different uses for bamboo. Many species are grown as ornamental plants, while others are used to control erosion in degraded areas, as a source of raw material for the structure of housing, as forage, as a source of fibre for the pulp and paper industry and as a source of biomass for energy production; the edible shoots are used for food. In addition, bamboo serves as raw material for craftsmen, making it a useful resource in local economies (FILGUEIRAS et al., 2013; FILGUEIRAS; GONÇALVES; 2004; RESENDE et al., 2011).

Bamboos form a monophyletic group within the Poaceae family, and can be recognised by their morphological, anatomical, embryological, physiological, cytological, macromolecular and ecological characteristics. These characteristics are used by researchers to identify, qualify, characterise, name, classify and recommend uses for the various species that make up this rich and diverse group of plants (FILGUEIRAS; GONÇALVES, 2011). One of the more interesting features among bamboos is related to flowering. Flowering in most species of bamboo is irregular until the end of the vegetative stage, a stage that can last up to 120 years (AZZINI; CLARAMELLO; NAGAI, 1978). After flowering some species die, making study of the floral characteristics of the bamboo difficult; they also produce a small number of seeds (RAMANAYAKE, 2006).

Most current classifications of the bamboo depend on morphological characteristics (CLARK et al., 2007), however few species have been properly documented, making it difficult to use phenotypic features. This is further compounded by the fact that taxonomic studies traditionally depend on inflorescence and floral morphology, since vegetative characteristics can be influenced by environmental conditions (SHALINI et al., 2013; YEASMIN et al., 2015).
Genetic diversity in the bamboo should be studied, providing data to investigate evolution of the bamboo through speciation (FILGUEIRAS; GONÇALVES, 2011). In addition, for bamboo to be seen as a viable alternative for its many uses, studies are necessary, so as to characterise and evaluate possible species for use in appropriate applications. However, studies into the characterisation and evaluation of bamboo species are scarce, and there is as yet no definitive list of morphological descriptors. The aim of this study therefore, was to propose and test the efficiency of qualitative and quantitative descriptors, with a view to the phenotypic characterisation and to the study of genetic diversity among six species of bamboo introduced into Brazil.

\section{MATERIAL AND METHODS}

Six accessions were used in the study, representing different species of bamboo (Bambusa vulgaris, Bambusa vulgaris var. vittata, Drepanostachyum falcatum, Dendrocalamus latiforus, Phyllostachys aurea var. albovariegada and Phyllostachys edulis). All material was provided by the Biomudas Laboratory, which maintains a collection of bamboos at Venda Nova do Imigrante, in the State of Espírito Santo (ES), Brazil. Plantlets from each species were obtained by the division method, used in the propagation of bamboo, where parts were taken from the rhizome and culm, and planted in 30-litre pots containing Basaplant ${ }^{\circledR}$ Florestais substrate.

The experiment was carried out in a greenhouse of the Research Support Unit (UAP) of the Darcy Ribeiro North Fluminense State University (UENF), at Campos dos Goytacazes, in the State of Rio de Janeiro (RJ), located at $21^{\circ} 45^{\prime} \mathrm{S}$ and $41^{\circ} 20^{\prime} \mathrm{W}$ at an average altitude of 11 metres.

Morphological characterisation was performed for two plants per species after around one year of growth. These were properly identified using bamboo identification keys to confirm the species (SHIRASUNA, 2012; WONG, 2004).

Vegetative morphological characteristics which are noticeably variable, from such parts of the plant as the culm, branches, leaves, petioles, sheath, ligule and buds, were used to make up the proposed descriptors for the species being studied, resulting in 15 qualitative and nine quantitative characteristics (Tables 1 and 2). For the qualitative characteristics, which involved establishing the colour, a scale was used to determine colour intensity. The quantitative characteristics were measured with the aid of a digital calliper, metal tape measure and millimetre rule. 
Table 1 - Proposed qualitative descriptors for the bamboo species: B. vulgaris, B. vulgaris var. vittata, D. falcatum, D. latiforus, P. aurea var. albovariegada and P. edulis.

\begin{tabular}{lcc}
\hline \multicolumn{1}{c}{ Descriptor name } & Abbreviation & Evaluation \\
\hline Culm sheath colouration & SC & 1: Green 2: Green-yellow 3: Green-white \\
Culm sheath wax & CSW & 1: Absent 1: Present \\
Culm colour & CC & 1: Green 2: Green-white \\
Blade colour & BC & 0: Absent 1: Present \\
Presence of node characteristics & NC & 1: Indistinct 2: Evident \\
Auricle development & AD & 1: Indistinct 2: Evident \\
Ligule development & LD & 0 : Absent 1: Present \\
Internode spikes & IS & 1: Cylindrical 2: Crooked \\
Shape of culm & CS & 1: Glabrous 2: Pilose \\
Culm sheath pilosity & SP & 1: Glabrous 2 Pilose \\
Internode pilosty & IP & 1: Glabrous 2: Pilose \\
Blade pilosity & BPI & 1: Erect 3: Hanging 5: Intermediate \\
Sheath blade position & BP & 1: Hollow 2: Solid \\
Internode filling & IF & 1: Uniform 2: Striped \\
Variation in culm colouration & VC
\end{tabular}

Table 2 - Proposed quantitative descriptors for the bamboo species: B. vulgaris, B. vulgaris var. vittata, D. falcatum, D. latiforus, $P$. aurea var. albovariegada and P. edulis.

\begin{tabular}{|c|c|c|}
\hline Descriptor name & Abbreviation & Evaluation \\
\hline Plant height & $\mathrm{PH}$ & In metres, from the ground to the highest leaf on the plant \\
\hline Length of internode & IL & $\begin{array}{l}\text { In centimetres, measured between } 2 \text { nodes from the } 1 \text { st to the } 5 \text { th } \\
\text { internode on the culm }\end{array}$ \\
\hline Length of leaf & LL & In centimetres, from the base to the tip of the leaf blade in 5 leaves \\
\hline Length of culm sheath & SL & $\begin{array}{l}\text { In millimetres, from the base of the sheath to the start of the } \\
\text { pseudopetiole in } 5 \text { sheaths }\end{array}$ \\
\hline Length of pseudopetiole & LP & $\begin{array}{l}\text { In millimetres, from the base of the pseudopetiole to the start of the } \\
\text { blade in } 5 \text { leaves }\end{array}$ \\
\hline Diameter of culm & $\mathrm{CD}$ & $\begin{array}{l}\text { In millimetres, from the basal, median and apical regions of the first } \\
\text { internode }\end{array}$ \\
\hline Width of leaf & LW & In millimetres, from one side to the other in 5 leaves \\
\hline Number of buds per node & NB & Counting the number of buds on the largest culm \\
\hline Number of branches per bud & BB & Counting the number of emerging branches in 5 buds \\
\hline
\end{tabular}

Genetic divergence between the species, and multivariate analysis using the mean Euclidean distance as a measure of dissimilarity, were determined by Tocher clustering optimisation (RAO, 1952), mean hierarchical clustering between groups (UPGMA), and principal component analysis. All analyses of genetic divergence were performed using the GENES software (CRUZ, 2013).

\section{RESULTS AND DISCUSSION}

For the qualitative features, no variability was seen in the descriptors of node characteristics (NC), internode spikes (IS), shape of culm (CS), internode pilosity (IP), blade position (BP) and internode filling (IF). Therefore these descriptors did not contribute to differentiating between the species (Table 3). 
Table 3 - Qualitative morphological characteristics in six bamboo genotypes, evaluated in a greenhouse

\begin{tabular}{|c|c|c|c|c|c|c|}
\hline & B. vulgaris & B. vulgaris vittata & D. falcatum & D. latiforus & P. aurea & P. edulis \\
\hline $\mathrm{SC}$ & Medium green & $\begin{array}{c}\text { Medium green } \\
\text { with yellow stripes }\end{array}$ & Light green & $\begin{array}{l}\text { Medium green with } \\
\text { yellow stripes }\end{array}$ & $\begin{array}{l}\text { Medium green } \\
\text { with white stripes }\end{array}$ & Medium green \\
\hline CSW & Absent & Absent & Absent & Absent & Present & Absent \\
\hline $\mathrm{CC}$ & Dark green & $\begin{array}{l}\text { Yellow with dark } \\
\text { green stripes }\end{array}$ & Light green & $\begin{array}{l}\text { Medium green with } \\
\text { dark green stripes }\end{array}$ & Medium green & Medium green \\
\hline $\mathrm{BC}$ & Dark Green & Dark green & Light green & Dark green & $\begin{array}{c}\text { Medium green } \\
\text { with white stripes }\end{array}$ & Dark green \\
\hline $\mathrm{NC}$ & Absent & Absent & Absent & Absent & Absent & Absent \\
\hline $\mathrm{AD}$ & Evident & Indistinct & Evident & Evident & Indistinct & Evident \\
\hline LD & Evident & Indistinct & Indistinct & Indistinct & Evident & Evident \\
\hline IS & Absent & Absent & Absent & Absent & Absent & Absent \\
\hline CS & Cylindrical & Cylindrical & Cylindrical & Cylindrical & Cylindrical & Cylindrical \\
\hline SP & Glabrous & Pilose & Glabrous & Pilose & Pilose & Pilose \\
\hline IP & Glabrous & Glabrous & Glabrous & Glabrous & Glabrous & Glabrous \\
\hline BPI & $\begin{array}{c}\text { L: Present R: } \\
\text { Absent E: Present }\end{array}$ & $\begin{array}{c}\text { L: Present R: } \\
\text { Present E: Present }\end{array}$ & $\begin{array}{c}\text { L: Present R: } \\
\text { Absent E: Present }\end{array}$ & $\begin{array}{c}\text { L: Absent R: Present } \\
\text { E: Present }\end{array}$ & $\begin{array}{c}\text { L: Absent R: } \\
\text { Absent E: Present }\end{array}$ & $\begin{array}{c}\text { L: Present R: } \\
\text { Present E: Present }\end{array}$ \\
\hline BP & Intermediate & Intermediate & Intermediate & Intermediate & Intermediate & Intermediate \\
\hline IF & Hollow & Hollow & Hollow & Hollow & Hollow & Hollow \\
\hline $\mathrm{VC}$ & Uniform & Striped & Uniform & Striped & Uniform & Uniform \\
\hline
\end{tabular}

Descriptors: culm sheath colouration (SC), culm sheath wax (CSW), culm colour (CC), blade colour (BC), presence of node characteristics (NC), auricle development (AD), ligule development (LD), internode spikes (IS), shape of culm (CS), culm sheath pilosity (SP), internode pilosity (IP), sheath blade pilosity (BPI) on the leaf blade (L), ribs (R) and edges (E), sheath blade position (BP), internode filling (IF) and variation in culm colour (VC)

For sheath colouration (SC), the species B. vulgaris vitatta and D. latiforus presented light green sheaths with yellow stripes. The species P. aurea albovariegada displayed sheaths of a green colouration with white stripes. The species B. vulgaris and P. edulis had medium green sheaths, and D. falcatum, light green, this being a feature that facilitated differentiation between the species. The presence of sheath wax (CSW) was only seen in $P$. aurea albovariegada (Table 3).

The species with a culm colouration (CC) of two colours are B. vulgaris vitatta, with yellow culms with dark green stripes, and $D$. latiforus, with medium green culms with dark green stripes. The species $P$. aurea albovariegada and $P$. edulis had medium green culms, $D$. falcatum had light green culms and B. vulgaris dark green culms (Table 3 ).

For the descriptor of leaf-blade colour (BC), the species $D$. falcatum displayed clear green leaf blades, in the species B. vulgaris, B. vulgaris vitatta, latiforus $D$. and $P$. edulis the blades had a dark green colouration, and in $P$. aurea albovariegada they were medium green with white stripes (Table 3). This characteristic for leaves of more than one colour encourages the use of the species as an ornamental plant. For the descriptor of auricle development (AD), evident auricles were seen in the species D. falcatum, B. vulgaris D. latiforus and P. edulis. At the junction of the blade and the sheath is the external ligule (LD), situated on the abaxial surface, and which may or may not be evident. Only the species B. vulgaris, $P$. edulis and $P$. aurea albovariegada displayed evident ligules (Table 3).

For the descriptor of sheath pilosity (SP), the species D. falcatum and B. vulgaris have glabrous sheaths, while those of the remaining species are pilose (Table 3 ).

Pilosity of the leaf blade (BPI) was evaluated for the blade (L), the ribs (R) and the borders (B). Pilosity was seen in the borders of the leaf blade in all the species under study, with the species $B$. vulgaris vittata and $P$. edulis presenting pilosity throughout the leaf-blade area. In the species $D$. falcatum and $B$. vulgaris, pilosity was seen on the blade, and in D. latiforus, pilosity was seen on the ribs (Table 3).

The quantitative characteristics contributed to differentiating between the species (Table 4). 
Table 4 - Quantitative morphological characteristics in six bamboo genotypes, evaluated in a greenhouse

\begin{tabular}{lcccccrrrr}
\hline \multicolumn{1}{c}{ Genotype } & PH & IL & LL & SL & LP & CD & LW & NB & BB \\
\hline B. vulgaris & 2.93 & 23.65 & 18.18 & 58.61 & 2.91 & 15.09 & 32.10 & 2.1 & 2.1 \\
B. vulgaris vittata & 3.05 & 23.76 & 21.88 & 62.85 & 3.39 & 22.45 & 31.85 & 3.2 & 3.2 \\
D. falcatum & 1.40 & 10.94 & 10.60 & 41.82 & 0.99 & 7.22 & 7.15 & 0.9 & 8.0 \\
D. latiforus & 2.84 & 23.38 & 16.66 & 65.95 & 3.04 & 13.00 & 29.46 & 4.6 & 4.6 \\
P. aurea albovariegada & 0.41 & 2.64 & 10.94 & 31.66 & 2.29 & 6.29 & 12.38 & 0.9 & 3.4 \\
P. edulis & 0.62 & 3.86 & 11.80 & 29.36 & 4.28 & 11.34 & 16.40 & 1.2 & 1.2 \\
\hline
\end{tabular}

Plant height $(\mathrm{PH})(\mathrm{m})$, length of internode (IL) (cm), length of leaf (LL) (cm), length of culm sheath (SL) (mm), length of pseudopetiole (LP) (mm), average diameter of culm (CD) (mm), width of leaf $(\mathrm{LW})(\mathrm{mm})$, number of buds per node (NB) and number of branches per bud (BB)

The method proposed by Singh (1981) made it possible to estimate the relative contribution of each quantitative descriptor to the genetic diversity between species. The quantitative characteristic that least contributed to differentiate between the species under study was seen to be plant height $(\mathrm{PH})(0.22 \%)$. The characteristics with the greatest contribution were the length of the culm sheath (SL) $(39.88 \%)$, width of the leaf (LW) (18.24\%) and length of the internodes (IL) (15.4\%) (Table 5).

Despite the low contribution of plant height to divergence, this descriptor cannot be ignored, as it is decisive when utilising the species. As pointed out by Wahab et al. (2010), plant height, number of internodes per culm, internode length and culm diameter are important factors in determining the most appropriate use for each species of bamboo.
When evaluating genetic divergence according to the values obtained for dissimilarity, the greatest genetic distance was between the species $B$. vulgaris vittata and $P$. aurea albovariegada (Table 6). The species involved belong to different genera and subtribes, which explains this result; the genus Bambusa belongs to the subtribe Bambusinae, while the genus Phyllostachys belongs to the subtribe Shibataeinae (DAS et al., 2008). The smallest genetic distance was found between the species $B$. vulgaris and D. latiforus (Table 6).

The Tocher method, when applied to qualitative data, allows for the formation of clusters based on the dissimilarity expressed by the divergence matrix obtained with the index ' $1-C$ ', where ' $C$ ' is the concordance of values expressed during comparison of the species. Thus, with the qualitative characteristics, the formation of three groups was seen, being a more restrictive

Table 5 - Relative contribution of quantitative characteristics to genetic divergence between six bamboo genotypes, using a method proposed by Singh (1981)

\begin{tabular}{lcc}
\hline \multicolumn{1}{c}{ Caracteristic } & Value \% & Accumulated \% \\
\hline Length of culm sheath & 39.88 & 39.88 \\
Width of leaf & 18.24 & 58.12 \\
Length of internodes & 15.70 & 73.82 \\
Culm diameter at the basal region of the 1st internode & 5.72 & 79.54 \\
Culm diameter at the median region of the 1st internode & 5.69 & 85.23 \\
Culm diameter at the apical region of the 1st internode & 5.29 & 90.52 \\
Average culm diameter & 4.58 & 95.1 \\
Length of leaf & 3.24 & 98.34 \\
Number of branches per node & 0.86 & 99.2 \\
Number of buds per node & 0.33 & 99.53 \\
Length of petiole & 0.25 & 99.75 \\
Plant height & 0.22 & 100.00 \\
\hline
\end{tabular}


Table 6 - Measures of dissimilarity between six bamboo genotypes based on the mean Euclidean distance

\begin{tabular}{|c|c|c|c|c|c|}
\hline Genotype & 2 & 3 & 4 & 5 & 6 \\
\hline 1. D. falcatum & 1.55 & 2.11 & 1.48 & 1.32 & 0.77 \\
\hline 2. B. vulgaris & & 0.81 & 0.63 & 1.23 & 1.50 \\
\hline 3. B. vulgaris vittata & & & 1.04 & 1.73 & 2.14 \\
\hline 4. D. latiforus & & & & 1.39 & 1.54 \\
\hline 5. P. edulis & & & & & 0.78 \\
\hline 6. P. aurea albovariegada & & & & & \\
\hline
\end{tabular}

method due to the use of discrete variables. Group 1 comprised the species $D$. falcatum, B. vulgaris and $P$. edulis. Group 2 included the species B. vulgaris vittata and $D$. latiforus. Finally, group 3 consisted of the species P. aurea albovariegada (Table 7).

Four groups were formed for the quantitative characteristics. Group 1 was composed of the species $B$. vulgaris and D. latiforus, group 2 of $D$. falcatum and $P$. aurea albovariegada, group 3 of $P$. edulis and group 4 of B. vulgaris vittata (Table 8).
The dendrogram of genetic similarity between the six bamboo genotypes, obtained by UPGMA, and based on the dissimilarity matrix of the qualitative data (Figure 1), showed that with a $40 \%$ cut it was possible to form four groups. The dendrogram based on the dissimilarity matrix of the quantitative data (Figure 2) showed that with $40 \%$ of the data, five groups were formed.

Principal component analysis reduced the nine quantitative characteristics to two principal

Table 7 - Groups of bamboo genotypes established by the Tocher method, based on the dissimilarity expressed by the mean Euclidean distance obtained from qualitative characteristics and descriptors that facilitated the formation of groups

\begin{tabular}{|c|c|c|}
\hline Group & Genotype & Descriptor \\
\hline 1 & D. falcatum, B. vulgaris and P. edulis & $\begin{array}{l}\text { Culm sheath wax, leaf blade colour, node characteristics, auricle } \\
\text { development, internode spikes, shape of culm, internode pilosity, } \\
\text { leaf-blade position and variation in culm colour }\end{array}$ \\
\hline 2 & B. vulgaris vitatta and D. latiforus & $\begin{array}{l}\text { Culm sheath colour, culm sheath wax, leaf-blade colour, node } \\
\text { characteristics, ligule development, internode spikes, shape of } \\
\text { culm, culm sheath pilosity, internode pilosity, leaf blade position, } \\
\text { internode filling and variation in culm colour }\end{array}$ \\
\hline 3 & P. aurea albovariegada & Culm sheath colour, culm sheath wax and leaf blade colour \\
\hline
\end{tabular}

Table 8 - Groups of bamboo genotypes established by the Tocher method, based on the dissimilarity expressed by the mean Euclidean distance obtained from quantitative characteristics that most contributed to the formation of groups

\begin{tabular}{ccc}
\hline Group & Genotype & Descriptor \\
\hline 1 & B. vulgaris e D. latiforus & Plant height, length of internodes and culm diameter \\
2 & D. falcatum e P. aurea albovariegada & Length of leaf and number of buds per node \\
3 & P. edulis & Length of pseudopetiole and culm diameter \\
4 & B. vulgaris vitatta & Length of leaf and culm diameter \\
\hline
\end{tabular}


Figure 1 - Dendrogram of the genetic similarity between six bamboo genotypes, obtained by UPGMA, and based on the dissimilarity matrix of the qualitative data

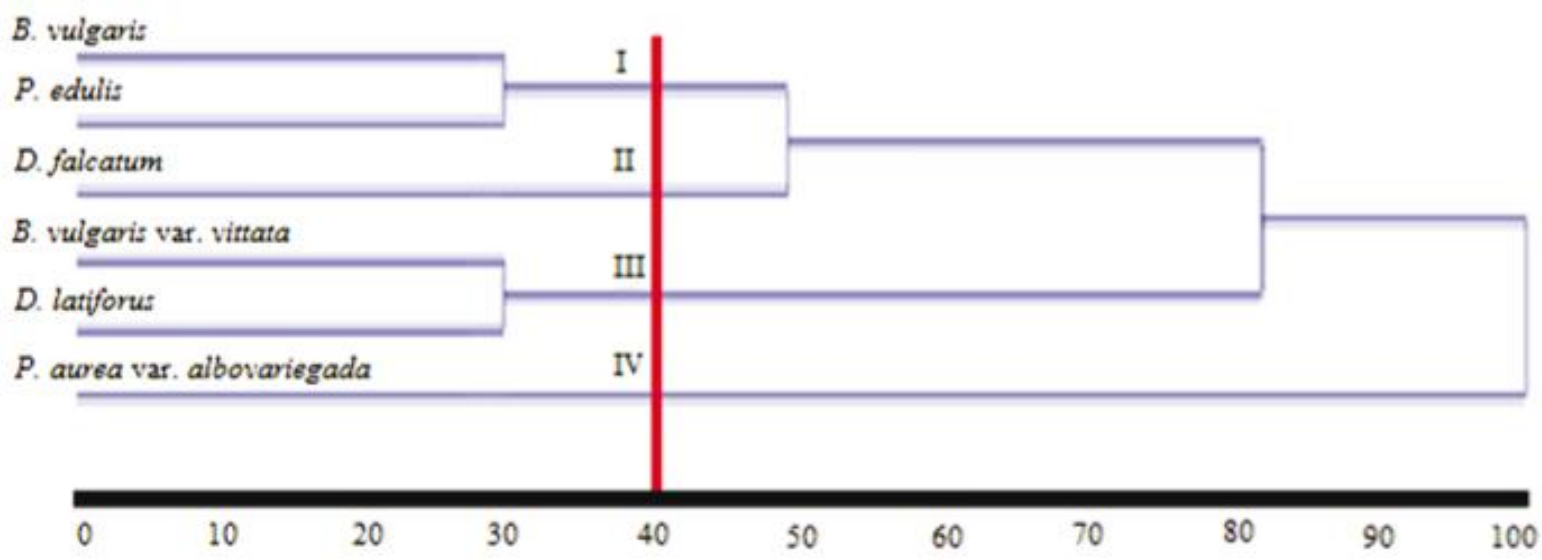

Figure 2 - Dendrogram of the genetic similarity between six bamboo genotypes, obtained by UPGMA, and based on the dissimilarity matrix of the quantitative data

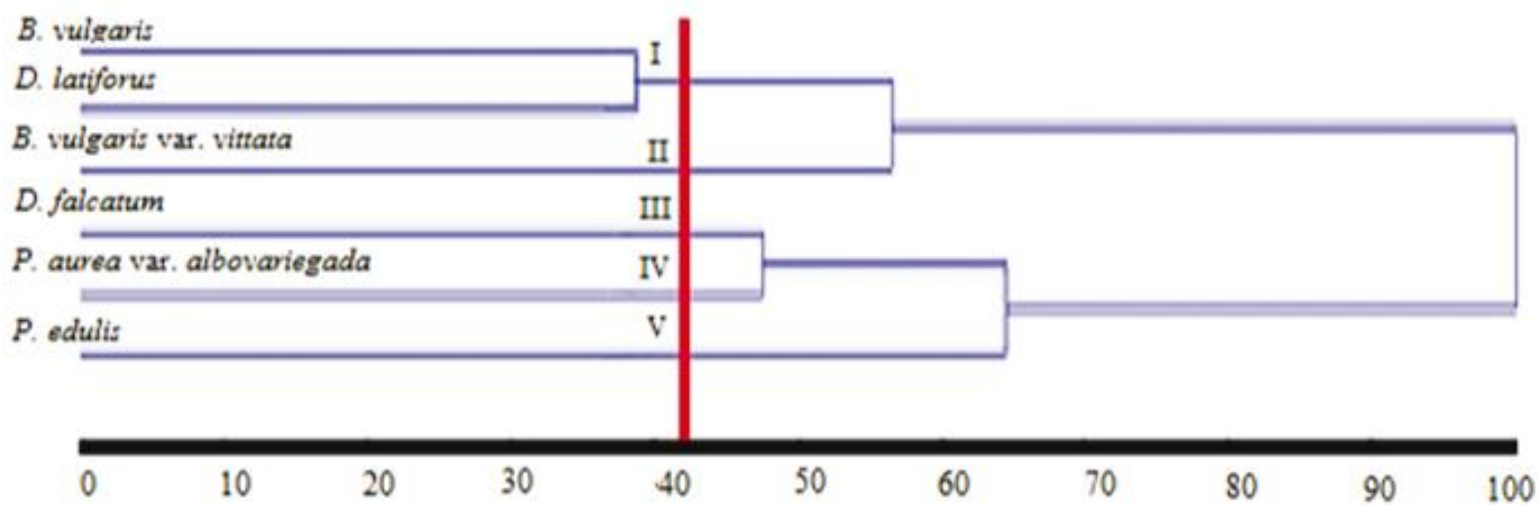

components (PC1 and PC2), which explained 91.44\% of the total variance between the six species. The greatest proximity was seen between the species $D$. latiforus (4) and B. vulgaris (2). The greatest distance was seen between the species $P$. aurea albovariegada (6) and B. vulgaris vittata (3) (Figure 3).

Based on the vegetative morphological descriptors, the species D. latiforus and B. vulgaris were seen to be very close. At the stage evaluated in this study, the two species are very similar. This was also noted by Sun, Xia and Lin (2005) where, by using ribosomal DNA as molecular markers in phylogenetic analysis, the species Bambusa and Dendrocalamus were allocated to the same group. According to $\mathrm{Li}$ (1997), there are similarities between many species of the genera Bambusa and Dendrocalamus, although the relationship between these genera is still not well understood.
Figure 3 - Principal component analysis (PC1 and PC2), with 91.44\% of accumulated variance, between six bamboo genotypes: (1) D. falcatum, (2) B. vulgaris, (3) B. vulgaris vittata, (4) D. latiforus, (5) P. edulis and (6) P. aurea albovariegada, based on quantitative characteristics

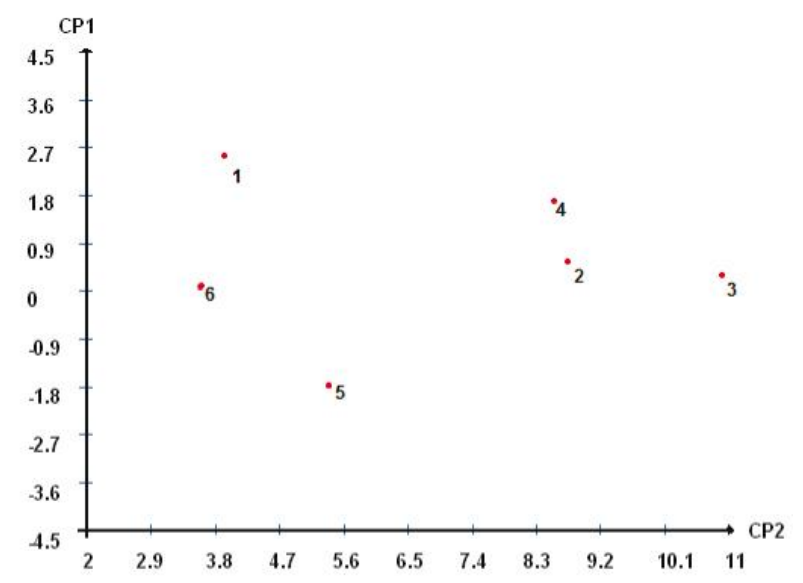


Classical systems for classifying bamboo are based on vegetative and reproductive morphological characteristics (DAS et al., 2007), although the reproductive characteristics of these plants often prevent such classification. Vegetative descriptors therefore, although they may be influenced by environmental conditions, are reliable and should be used in diversity studies.

In this work, high genetic diversity was seen between the six species under study using morphological descriptors; this was also observed by Das et al. (2007), who found high genetic diversity between 15 species of bamboo in India. Also, in studies involving different individuals of the same species, Bambusa Tulda, Bhattacharya et al. (2006) found little genetic diversity as would be expected. Further studies involving a large number of bamboos from different regions are therefore required to achieve a better understanding of their genetic diversity.

\section{CONCLUSIONS}

1. The proposed qualitative and quantitative descriptors were efficient in differentiating the species B. vulgaris, B. vulgaris var. vittata, D. falcatum, D. latiforus, $P$. aurea var. albovariegada and P. edulis;

2. The species showed high genetic diversity;

3. The largest contributor in differentiating between the species under study was the quantitative descriptor for length of sheath;

4. The species with the greatest genetic proximity were $D$. latiforus and B. vulgaris. The greatest distance was seen between the species $P$. aurea albovariegada and $B$. vulgaris vittata.

\section{ACKNOWLEDGEMENTS}

The authors wish to thank Capes for the grant of a masters scholarship to the lead author of this work. Thanks also go to Biomudas Laboratory for the donation of the plants used in the study.

\section{REFERENCES}

AZZINI, A.; CLARAMELLO, D.; NAGAI, V. Propagação vegetativa do bambu gigante. Bragantia, v. 37, n. 1, p. 1-3, 1978.

BAMBOO PHYLOGENY GROUP. An updated tribal and subtribal classification of the bamboos (Poaceae:
Bambusoideae). The Journal of the American Bamboo Society, v. 24, n. 1, p. 1-10, 2012.

BHATTACHARYA, S. et al. Morphological and molecular characterization of Bambusa tulda with a note on flowering. Annals of Botany, v. 98, p. 529-535, 2006.

CLARK, L. G. et al. Phylogenetic relationships among the one-flowered, determinate genera of Bambuseae (Poaceae: Bambusoideae). A Journal of Systematic and Evolutionary Botany, v. 23, n. 1, p. 315-332, 2007.

CRUZ, C. D. Genes:a software package for analysis in experimental statistics and quantitative genetics. Acta Scientiarum. v. 35, n. 3, p. 271-276, 2013.

DAS, M. et al. Bamboo taxonomy and diversity in the era of molecular markers. Advances in Botanical Research, v. 47, p. 225-267, 2008.

DAS, M. et al. Phylogenetic relationships among the bamboo species as revealed by morphological characters and polymorphism analyses. Biologia Plantarum, v. 51, n. 4, p. 667-672, 2007.

FILGUEIRAS T. S.; GONÇALVES, A. P. S. Bambus nativos no Brasil: oportunidades e desafios para seu conhecimento. In: SEMINÁRIO NACIONAL DO BAMBU: estruturação da rede de pesquisa e desenvolvimento, 1., 2006, Brasília. Anais.... 2. ed. Brasília: CPAB, Universidade de Brasília, 2011. p. 196.

FILGUEIRAS, T. S. et al. Poaceae. In: Lista de Espécies da Flora do Brasil. Jardim Botânico do Rio de Janeiro, 2013. Disponível em: http://floradobrasil.jbrj.gov.br/jabot/ floradobrasil/FB102232. Acesso em: 12 maio 2015.

FILGUEIRAS, T. S.; GONÇALVES, A. P. S. A checklist of the basal grasses and bamboos in Brazil (Poaceae). The Journal of the American Bamboo Society, v. 18, n. 1, p. 7-18, 2004.

GUERREIRO, C. I., LIZARAZU, M. A. Flowering of Bambusa tuldoides (Poaceae, Bambusoideae, Bambuseae) in southern South America. Darwiniana, v. 48, n. 1, p. 25-31, 2010.

LI, D. Z. The flora of China Bambusoideae project: problems and current understanding of bamboo taxonomy in China. In: The bamboos, v. 19, p. 61-81, 1997.

RAMANAYAKE, S. M. S. D. Flowering in bamboo: an enigma! Ceylon Journal of Science, v. 35, n. 2, p. 95-105, 2006.

RAO, R. C. Advanced statistical methods in biometric research. New York: J. Wiley, 1952. 330 p.

RESENDE, C. D. S. et al. Obtenção do extrato hidroalcoólico da Bambusa vulgaris vittata e avaliação da atividade antimicrobiana. In: SEMINÁRIO DE PESQUISAS E TCC DA FACULDADE UNIÃO DE GOYAZES, 2., 2011, Trindade,GO. Anais..., Trindade,GO, 2011. p. 1-24.

SHALINI, A. et al. Evaluation of genetic diversity in bamboo through DNA marker and study of association with morphological traits. Bulletin of Environment, Pharmacology and Life Sciences, v. 2, n. 8, p. 78-83, 2013. 
SHIRASUNA, R. T. Bambus nativos (Poaceae: Bambusoideae) no Parque Estadual das Fontes do Ipiranga, São Paulo, Brasil. 2012. 266 f. Dissertação (Mestrado em Biodiversidade Vegetal e Meio Ambiente) - Instituto de Botânica da Secretaria de Estado do Meio Ambiente, São Paulo, 2012.

SILVA, I. F.; PEREIRA, D. S.; SILVA, S. R. Estudos morfológicos do bambu (Bambusa cf. vulgaris), uma espécie invasora em área de Mata Atlântica no Parque Municipal de Maceió-Alagoas. Revista Semente, v. 6, n. 6, p. 99-109, 2011.

SINGH, D. The relative importance of characters affecting genetic divergence. Indian Journal of Genetic and Plant Breeding, v. 41, n. 2, p. 237-245, 1981.

SUN, Y.; XIA, N.; LIN, R. Phylogenetic analysis of Bambusa (Poaceae: Bambusoideae) based on internal transcribed spacer sequences of nuclear ribosomal DNA. Biochemical Genetics, v. 43, n. 12 p. 603-612, 2005.

SUNGKAEW, S. et al. Non-monophyly of the woody bamboos (Bambuseae; Poaceae): a multi-gene region phylogenetic analysis of Bambusoideae. Journal of Plant Research, v. 122, p. 95-108, 2009.

TOMBOLATO, A. F. C.; GRECO, T. M.; PINTO M. M. Dez espécies de bambus exóticos mais comuns no paisagismo no Brasil. Revista Brasileira de Horticultura Ornamental, v. 18, n. 2, p. 105-114, 2012.

WAHAB, R. et al. Anatomical and physical properties of cultivated two- and four-year-old Bambusa vulgaris. Sains Malaysiana, v. 39, n. 4, p. 571-579, 2010.

WONG, K. M. Bamboo: the amazing grass: a guide to the diversity and study of bamboos in Southeast Asia. Selangor Darul Ehsan, Malaysia: International Plant Genetic Resources Institute (IPGRI); Kuala Lumpur, Malaysia: University of Malaya, 2004. 80 p. Disponível em: http://www.bioversityinternational.org/. Acesso em: 02 dez. 2013.

YEASMIN, L. et al. Bamboo: an overview on its genetic diversity and characterization. 3 Biotech, v. 5, p. 1-11, 2015. 